\title{
Sol-Gel Syntheses of Zinc Oxide and Hydrogenated Zinc Oxide (ZnO:H) Phases
}

\author{
Joshua Lelesi Konne and Bright Obum Christopher \\ Department of Chemistry, Rivers State University of Science and Technology, Nkpolu, Oroworukwo, Port Harcourt, Nigeria \\ Correspondence should be addressed to Joshua Lelesi Konne; konne.joshua@ust.edu.ng
}

Received 26 June 2016; Revised 29 November 2016; Accepted 5 December 2016; Published 5 January 2017

Academic Editor: Marco Rossi

Copyright (C) 2017 J. L. Konne and B. O. Christopher. This is an open access article distributed under the Creative Commons Attribution License, which permits unrestricted use, distribution, and reproduction in any medium, provided the original work is properly cited.

\begin{abstract}
$\mathrm{ZnO}$ synthesized by chemical precipitation with varying starch concentrations $(0.00,0.01,0.02,0.05,0.10,0.15$, and $0.20 \%)$ as stabilizing agent was used in making $\mathrm{ZnO}: \mathrm{H}$ when placed in a glass tube under mild heat and hydrogen $\left(\mathrm{H}_{2}\right)$ gas flow for 2 mins. Observations showed that the sample colour changed from white to light brown and finally to dark brown during the process particularly for the $\mathrm{ZnO}$-starch samples. $\mathrm{XRD}$ data of $\mathrm{ZnO}(0.02 \%)$ and $\mathrm{ZnO}: \mathrm{H}(0.02 \%)$ showed $\mathrm{ZnO}$ as the major phase with $\mathrm{Zn}(\mathrm{OH})_{2}$ impurity phase and a new $\mathrm{ZnO}: \mathrm{H}$ peak at $2 \theta, 29.60^{\circ}$ for $\mathrm{ZnO}$ and $\mathrm{ZnO}: \mathrm{H}$, respectively. The estimated particle sizes determined from XRD were 47 and $30 \mathrm{~nm}$, respectively. The SEM of the $0.02 \% \mathrm{ZnO}$ appeared more microporous and needlelike than those of $0.01 \%$, while the EDX of both confirmed $\mathrm{Zn}$ and $\mathrm{O}$ as the main components. Different conductivities of 30.90 and $27.50 \mu \mathrm{S} / \mathrm{cm}$ were obtained for $\mathrm{ZnO}$ and $\mathrm{ZnO}: \mathrm{H}$ samples in ethanol, respectively. Also, the UV-Vis absorption for both showed n-type and p-type material absorption bands at $310 \mathrm{~cm}^{-1}$, while the intensities of all the characteristic ZnO IR bands at $430-552$ (ZnO vibrations) and $1500-1640 \mathrm{~cm}^{-1}$ ( $\mathrm{Zn}-\mathrm{O}$ stretching) increased for the corresponding $\mathrm{ZnO}: \mathrm{H}$ samples.
\end{abstract}

\section{Introduction}

The compositions of Rock-Salt structures of some 3D-metal monoxides (MOs) like $\mathrm{ZnO}$ among others are mostly nonstoichiometric with defects and vacancies on either their cationic or anionic sites. These inherent variable compositions influence the electrical, mechanical, spectral, optical, magnetic, catalytic, antimicrobial, and even metallic properties of the MOs [1]. Hence MOs like $\mathrm{ZnO}$ find applications such as light diodes, transparent conductors, photocatalysts, photoprinting, solar cells, lasers, sensors, body powder, sunscreen and medicated creams, UV resistant coatings, capacitors, and varistor-electronic devices [2-4].

$\mathrm{ZnO}$ has a Wurtzite structure that exists in two phases as $\mathrm{Zn}_{1-x} \mathrm{O}$ or $\mathrm{ZnO}_{1-x}$ depending on whether it is zinc deficient or zinc rich [1]. The two phases occur naturally during synthesis and are referred to as "native defects." While the zinc deficient phase is a strong electron acceptor, the oxygen deficient phase is a strong donor. In the donor form $\left(\mathrm{ZnO}_{1-x}\right), \mathrm{ZnO}$ exhibits strong $\mathrm{n}$-type semiconductivity in which electrical conductivity decreases due to withdrawal of electrons from the conduction band. Oxygen deficient phase has been attributed to the presence of commonly associated impurities such as hydrogen on the oxygen sites [5-7]. $\mathrm{ZnO}$ with n-type conductivity finds application for use in transparent solar cell conductors and displays and as bilayer for low-cost thin film electronics $[8,9]$.

The morphological control over crystallization of $\mathrm{ZnO}$ from nitrate salt and sodium hydroxide precursors has been found to be route, $\mathrm{pH}$, temperature, and concentration dependent $[2,4]$. Therefore $\mathrm{ZnO}$ has been synthesized by microemulsion [3], paper [10], hydrothermal [11] and mechanochemical decomposition [12], microwave-assisted [13], ionic-template [14], solvothermal [15], and pulsed Laser deposition [16], sol-gel (using zinc acetate, folic acid, and starch), and so forth for various applications [17-19]. Solgel technique is cheap and easy and produces purer high surface materials amongst others. However, the applications of these techniques including sol-gel in the production of intentionally synthesized hydrogenated zinc oxide nanoparticles $(\mathrm{ZnO}: \mathrm{H})$ phases have not been widely reported. 


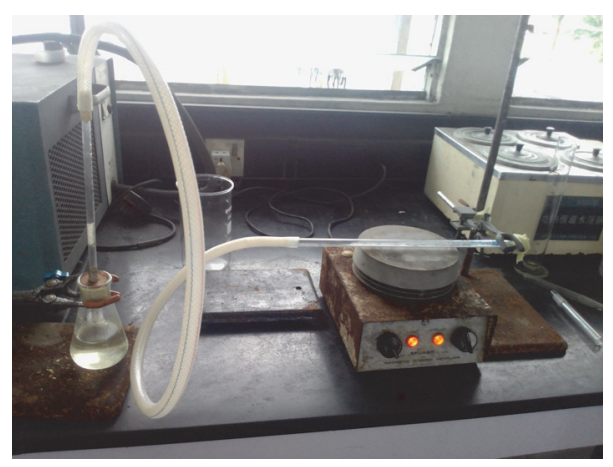

(a)

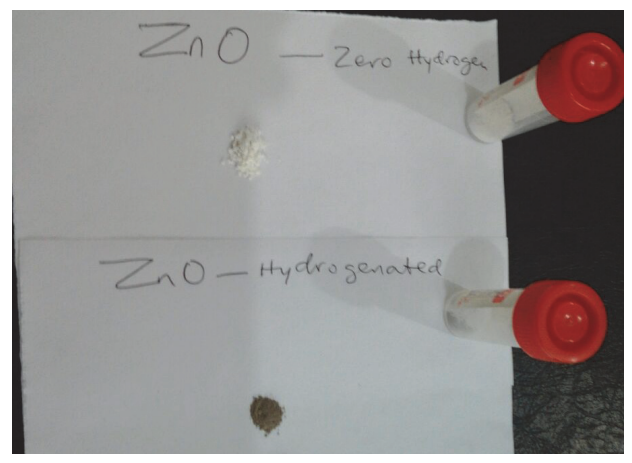

(b)

Figure 1: (a) Hydrogenation of $\mathrm{ZnO}$ heated at $55^{\circ} \mathrm{C}$ using $\mathrm{Mg}$ ribbon dissolved in $6 \mathrm{M} \mathrm{HCl}$ and (b) labelled samples before and after hydrogenation.

Theoretical ab initio simulations have shown that hydrogen $\left(\mathrm{H}^{+}\right)$ion substitutes oxygen vacancy forming a fourfold coordination with $\mathrm{Zn}$ atoms in hydrogenated $\mathrm{ZnO}$, while $\mathrm{Zn}$ vacancy (which results in p-type conductivity) is substituted by two hydrogen atoms $[6,20]$. Thus, a well-hydrogenated $\mathrm{ZnO}$ phase should have some structural changes (due to lattice adjustments for $\mathrm{H}$ insertion) that would affect $\mathrm{Zn}-\mathrm{O}$ vibrations, UV absorption, and electrical conductivity [2123]. Therefore, the adoption of a suitable synthetic strategy for $\mathrm{ZnO}: \mathrm{H}$ could produce the desired control over n-type conductivity in $\mathrm{ZnO}$. However, the available studies have not demonstrated such structural changes due to $\mathrm{H}$ insertion in hydrogenated $\mathrm{ZnO}$ phase using XRD. This report presents an adaptable approach to the sol-gel synthesis of hydrogenated $\mathrm{ZnO}$ nanoparticles ( $\mathrm{ZnO}: \mathrm{H})$, UV-Vis study, X-ray diffraction, electrical conductivity analyses, and Infrared spectroscopic studies of both phases with varying particle sizes.

\section{Experimental}

2.1. Synthesis of $\mathrm{ZnO}$ Nanoparticles. Zinc oxide nanoparticles were synthesized by a modified wet chemical method involving the precipitation of zinc hydroxide, $\mathrm{Zn}(\mathrm{OH})_{2}$, from the reaction of $0.1 \mathrm{~mol}$ zinc nitrate and $0.2 \mathrm{~mol}$ sodium hydroxide solutions followed by overnight drying of the precipitates at $80^{\circ} \mathrm{C}$ to form $\mathrm{ZnO}$ [19]. Varying masses of starch $(0.01$, $0.02,0.05,0.10,0.15$, and $0.20 \mathrm{~g}$ ) were weighed and dissolved in $100 \mathrm{~mL}$ of deionized water to give the different \% (w/v) concentrations. These solutions were boiled at $100^{\circ} \mathrm{C}$, cooled, and used for the dissolution of precursors before reaction. Modifications to previous report [19] included direct boiling of starch solution (not microwaving), separation by decantation and filtration (not centrifuging), and use of boiled starch solutions for dissolution of precursors.

2.2. Synthesis of $\mathrm{ZnO}: \mathrm{H}$ Nanoparticles. The generation of hydrogen $\left(\mathrm{H}_{2}\right)$ gas was achieved by the reaction of 10 pieces of $\mathrm{Mg}$ ribbon dissolved in $50 \mathrm{~mL}$ of $6 \mathrm{M} \mathrm{HCl}$ in a conical flask. The liberated hydrogen was passed over $\mathrm{ZnO}$ nanoparticles under mild heat $\left(55^{\circ} \mathrm{C}\right)$ in a glass tube well clamped slightly above a heating mantle surface for 3 mins. The hydrogenation process was repeated thrice for one of $0.02 \%$ sample in order to investigate the effect of higher $\mathrm{H}$-concentration. The setup for the process is shown in Figure 1(a). The colour of the $\mathrm{ZnO}$ nanoparticles changed from white to brown and finally to dark brown or black for the starch coated samples (Figure 1(b)). However, no visible change was observed for the control sample without starch $(0 \%)$. The samples over which hydrogen gas was passed were tagged as $\mathrm{ZnO}: \mathrm{H}_{(a)}$ and $\mathrm{ZnO}: \mathrm{H}_{(\mathrm{b})}$ (hydrogenated process repeated thrice) samples, respectively.

2.3. Characterization. The X-ray diffraction (XRD) analyses of samples of $0.02 \%$ starch $\left(\mathrm{ZnO}: \mathrm{H}_{(\mathrm{a} \& \mathrm{~b})}\right.$ and $\left.\mathrm{ZnO}\right)$ were carried out on a GBC Enhanced Mini-Material Analyzer. The samples were ground into fine (homogeneous) powder, pelletized, and loaded on a silicon sample holder. Pelletizing was done in order to enhance smooth sample surface necessary for low noise output. The $2 \theta$ angle range of $10-60^{\circ} \mathrm{C}$ within which major reflections of $\mathrm{ZnO}$ appear was selected with a step size of 0.05. Similarly, the conductivities of two samples $\mathrm{ZnO}$ and $\mathrm{ZnO}: \mathrm{H}_{(\mathrm{a})}$ dispersed in $10 \mathrm{~mL}$ ethanol were carried out with an Extech D0700 Conductivity Instrument. The same samples were used for a UV-Vis scan between 300 and $500 \mathrm{~nm}$ on a 2500 LaboMed spectrophotometer. The SEM samples were prepared by placing a little of the samples on carbon sticky pads. These were placed on labeled aluminum stubs prior to analysis on an SEM model ASPEX 3020 equipped with an Oxford EDX detector. The two starched samples first used for SEM and EDX analyses were those of the 0.01 and $0.02 \% \mathrm{ZnO}$ samples only due to cost. Later, the SEM and energy dispersive spectroscopy (EDS) of both $0.02 \%\left(\mathrm{ZnO}\right.$ and $\left.\mathrm{ZnO}: \mathrm{H}_{(\mathrm{b})}\right)$, respectively, were also carried out in order to investigate possible impact of $\mathrm{H}$ insertion on the $\mathrm{ZnO}$ microstructures. Samples for FT-IR were ground with $\mathrm{KBr}$ and pelletized into circular discs for analysis on a PerkinElmer Spectrum 10.4.3 Infrared spectrophotometer. Each disc was placed in a sample holder positioned in the path 


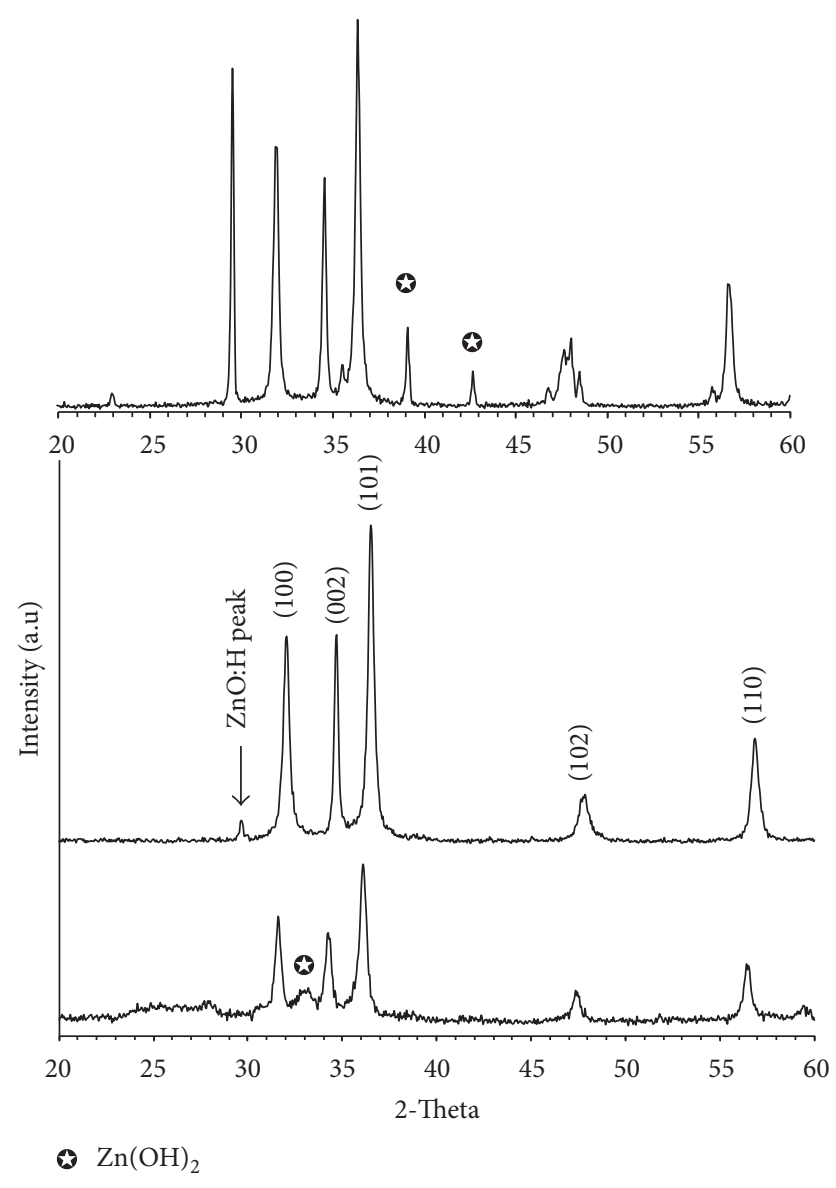

FIGURE 2: XRD patterns of $0.02 \%$ starch-mediated ( $\mathrm{ZnO}$-bottom, $\mathrm{ZnO}: \mathrm{H}_{(\mathrm{a})}$-middle, and $\mathrm{ZnO}: \mathrm{H}_{(\mathrm{b})}$-top) samples, respectively.

of Infrared radiation operating at a selected wavelength range of 350-4000 $\mathrm{nm}$ before the analysis on a read out computer.

\section{Results and Discussion}

3.1. XRD, Conductivity, and SEM Characterizations. The XRD patterns of the $\mathrm{ZnO}$ (bottom) and $\mathrm{ZnO}: \mathrm{H}_{(\mathrm{a} \& \mathrm{~b})}$ (top) plots for the $0.02 \%$ starch-mediated $(\mathrm{ZnO}$ and $\mathrm{ZnO}: \mathrm{H})$ samples, respectively, are shown in Figure 2. The major reflections of the samples were indexed to a hexagonal synthetic zincite of the space group, P63mc (186), using the Joint Committee on Powder Diffraction Standards (JCPDS) card number 00$005-0664$ [24]. $c$-axis (002) was calculated as $0.520 \mathrm{~nm}$ and this matched with the reference card value of $0.5205 \mathrm{~nm}$.

However, the $\mathrm{ZnO}$ and $\mathrm{ZnO}: \mathrm{H}_{(\mathrm{b})}$ samples showed reflections of minor $\mathrm{Zn}(\mathrm{OH})_{2}$ impurity phase at $2 \theta, 33.20(\mathrm{ZnO})$, 39.10 and $42.65^{\circ}\left(\mathrm{ZnO}: \mathrm{H}_{(\mathrm{b})}\right)$, respectively, indexed to JCPDS card 38-385 [4], while both $\mathrm{ZnO}: \mathrm{H}_{(\mathrm{a})}$ and $\mathrm{ZnO}: \mathrm{H}_{(\mathrm{b})}$ showed the emergence of a new peak due to $\mathrm{ZnO}$ hydrogen bonded ( $\mathrm{ZnO}: \mathrm{H})$ phases at $2 \theta, 29.60^{\circ}$, respectively. The enhancement of the peak assigned to $\mathrm{ZnO}: \mathrm{H}$ as shown by the second sample $\left(\mathrm{ZnO}: \mathrm{H}_{(\mathrm{b})}\right)$ where the hydrogenation process was repeated thrice (top image of Figure 2) confirmed the peak position. Moreover, the intermediate product, $\left(\mathrm{Zn}(\mathrm{OH})_{2}\right)$ does not reflect at such angle. Particle size estimations were evaluated from Scherrer's formula (see (1)) below:

$$
\left[d=\frac{k \lambda}{\beta \cos \theta}\right]
$$

where $d$ is mean particle diameter (size), $\lambda$ is $\mathrm{Cu} \mathrm{K} \alpha 1$ radiation $=0.154 \mathrm{~nm}, \beta$ is Full Width at Half Maximum (FWHM) (in radians), and $\theta$ is half of $2 \theta$ angle (radians), respectively. The particle sizes estimated for the three samples were $47(\mathrm{ZnO})$, $37\left(\mathrm{ZnO}: \mathrm{H}_{(\mathrm{b})}\right)$, and $30 \mathrm{~nm}\left(\mathrm{ZnO}: \mathrm{H}_{(\mathrm{a})}\right)$ samples, respectively.

The difference in particle sizes of $\mathrm{ZnO}$ and $\mathrm{ZnO}: \mathrm{H}_{(\mathrm{a} \& \mathrm{~b})}$ samples could be attributed to hydrogen replacement of $\mathrm{O}$ atom in the $0.02 \%$ starch-mediated $\mathrm{ZnO}$ since the same sample (size) was used for $\mathrm{ZnO}: \mathrm{H}_{(\mathrm{a \& b})}$ synthesis and as such no change should have occurred except from $\mathrm{H}$ replacement of $\mathrm{O}$ atom in a fourfold coordinated position $[6,21]$. In addition, the presence of $\mathrm{Zn}(\mathrm{OH})_{2}$ impurities could also be a factor as observed for the size variation between $\mathrm{ZnO}: \mathrm{H}_{(\mathrm{a})}$ and $\mathrm{ZnO}: \mathrm{H}_{(\mathrm{b})}$. Hydrogen doping which causes reduced conductivity in $\mathrm{ZnO}$ was also found to be responsible for the different conductivities of 30.90 and $27.50 \mu \mathrm{S} / \mathrm{cm}$ obtained for $\mathrm{ZnO}$ and $\mathrm{ZnO}: \mathrm{H}_{(\mathrm{a})}$ samples, respectively, in ethanol. The conductivity of the ethanol used was $8.41 \mu \mathrm{S} / \mathrm{cm}$.

Furthermore, higher $d$-spacing was also obtained for $\mathrm{ZnO}$ compared to those of $\mathrm{ZnO}: \mathrm{H}$ for the same peak positions. For instance, $d$-spacing of $\mathrm{ZnO}$ for (100) peak was 2.829, while those of $\mathrm{ZnO}: \mathrm{H}_{(\mathrm{a})}$ and $\mathrm{ZnO}: \mathrm{H}_{(\mathrm{b})}$ were 2.791 and 2.803 , respectively, for the same peak position. Table 1 of the supplementary data sheet in Supplementary Material available online at https://doi.org/10.1155/2017/5219850 contained $d$-spacing of major peaks of the samples. These narrow shifts in peak positions ( $d$-spacings) could be due to strain effects from inhomogeneity caused by $\mathrm{H}$ insertion. However, small changes in lattice parameters would only be observed in the case of uniform dilatation (equally strained polycrystallites) like those of $\mathrm{ZnO}: \mathrm{H}_{(b)}$ with higher hydrogen concentration compared to $\mathrm{ZnO}: \mathrm{H}_{(\mathrm{a})}$ [25].

The same starch solution (gel) was used for all three samples and this enhanced homogeneous nucleation of $\mathrm{Zn}(\mathrm{OH})_{2}$ clusters and subsequent crystal growth of zinc oxide nanoparticles during the drying process. This effect is reflected in similar broad peaks and backgrounds observed in the XRD patterns of all three samples (Figure 2). The change in colour of the hydrogenated starch-mediated samples from white to brown and finally dark brown as shown in Figure 1 would be due to the presence of oxygen atoms on starch molecules in addition to those provided by $\mathrm{ZnO}$ groups compared to nonstarch-mediated $\mathrm{ZnO}$ samples. The estimated particle size of $\mathrm{ZnO}$ obtained was slightly lower than $\sim 50 \mathrm{~nm}$ reported for similar starch-mediated method with $0.1 \%$ starch [19].

The SEM images of two (0.01 and $0.02 \%$ starch-mediated) samples showed morphological differences of the synthesized $\mathrm{ZnO}$ nanoparticles as shown in Figures 3(a) and 3(b), respectively. Similar controls of crystal sizes with changing starch concentration have been reported previously [26]. The image in Figure 3(a) shows polycrystallite clusters of varying sizes in the form of porous agglomerates, while a more porous fiber-like network was observed in Figure 3(b) (0.02\% 


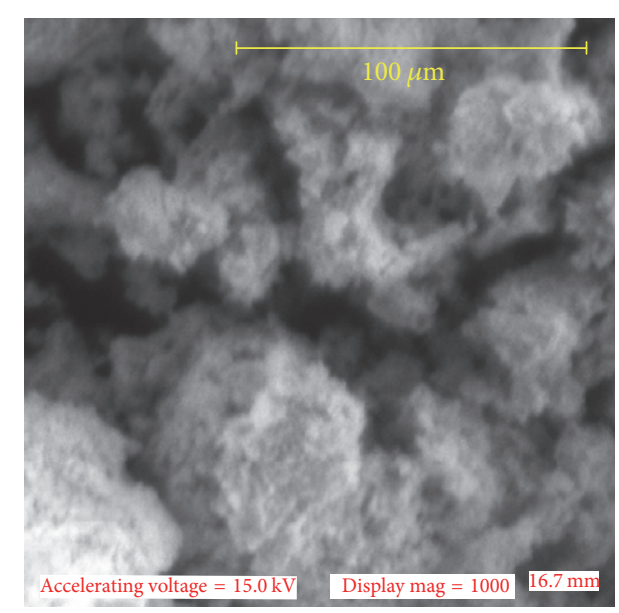

(a)

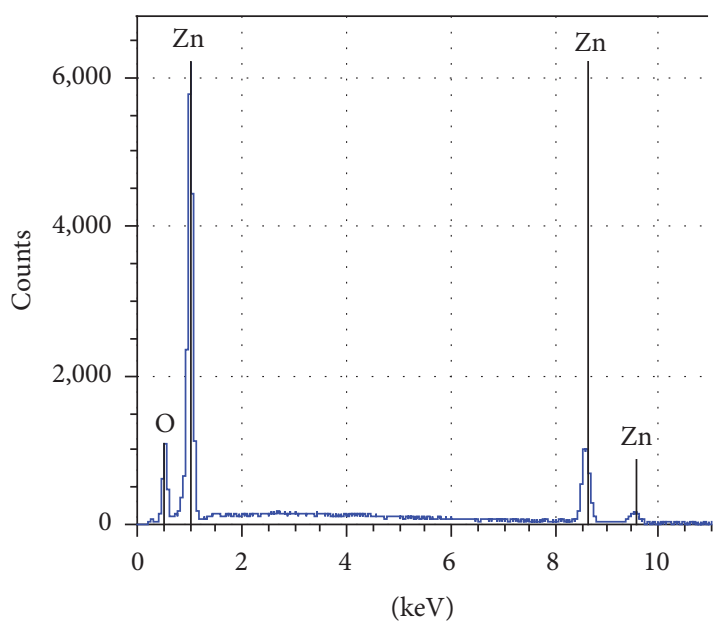

(c)

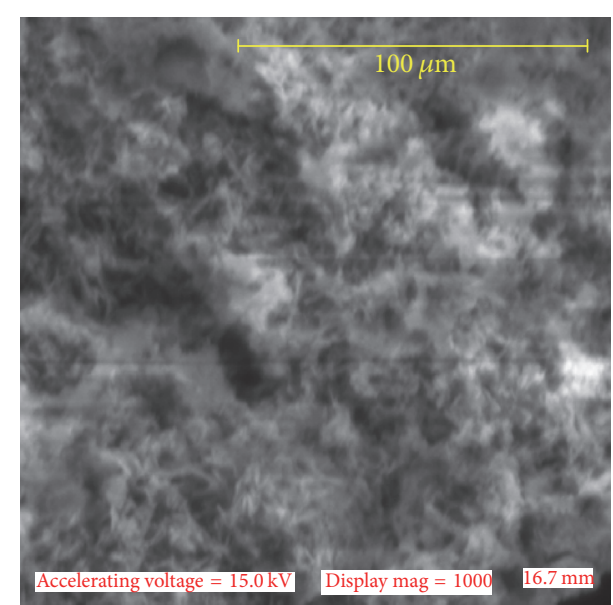

(b)

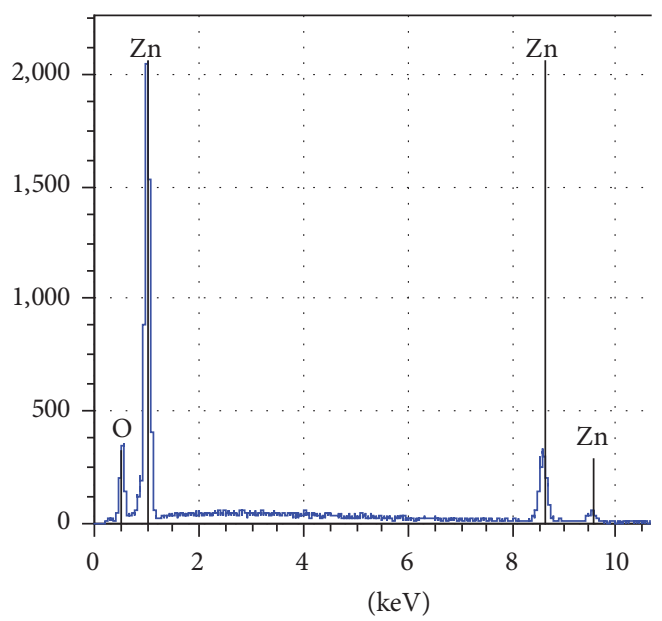

(d)

FIgURE 3: (a-b) SEM micrographs and (c-d) EDX spectra of $0.01 \%$ and $0.02 \%$ starch-mediated ZnO samples, respectively.

starch-mediated sample). The EDX spectra of both samples confirmed the presence of zinc and oxygen only in the two samples as shown in Figures 3(c) and 3(d), respectively.

Similarly, the SEM micrographs of the $0.02 \%$ starch $\mathrm{ZnO}$ at both higher and lower magnifications (Figures 4(a) and 4(b)) and those of $\mathrm{ZnO}: \mathrm{H}_{(\mathrm{b})}$ (Figures 4(c) and 4(d)) at similar magnifications are shown in Figure $4 . \mathrm{ZnO}: \mathrm{H}_{(\text {b) }}$ was selected for SEM analysis because of its higher hydrogen content than $\mathrm{ZnO}: \mathrm{H}_{(\mathrm{a})} . \mathrm{ZnO}$ at higher magnification with scale bar of $200 \mathrm{~nm}$ (Figure 4(a)) showed aggregates of thick-joint polycrystallites separated by pores, while the lower magnification (with $500 \mathrm{~nm}$ scale bar) showed a more compact microporous polycrystallite structure (Figure 4(b)). The higher magnified SEM micrographs (scale bar of $100 \mathrm{~nm}$ ) of $\mathrm{ZnO}_{(\mathrm{H})}$ in Figure 4(c) showed smaller grains of joint polycrystallites on top of larger ball-like structured materials with wider pores. The smaller crystallites could be the hydrogenated zinc oxide polycrystallites. However, at lower magnification with $500 \mathrm{~nm}$ scale bar (Figure 4(c)), an orderly etched monophasic surface was observed. The EDS of both samples appear on Figures 4(a) and 4(d) for $\mathrm{ZnO}$ and $\mathrm{ZnO}: \mathrm{H}_{(\mathrm{b})}$ samples, respectively. They showed $\mathrm{Zn}$ as the major components of both samples with $\mathrm{ZnO}: \mathrm{H}_{(\mathrm{b})}$ having lower $\mathrm{Zn}$ content of $54.42 \%$ compared to $56.68 \%$ of $\mathrm{ZnO}$. Other elements (impurities) found on both EDS were $\mathrm{Si}, \mathrm{Mn}, \mathrm{Fe}, \mathrm{Ti}$, and $\mathrm{Ca}$.

3.2. UV-Vis and IR Characterizations. A scan of the $\mathrm{ZnO}: \mathrm{H}_{(\mathrm{a})}$ sample in ethanol from 500 to $300 \mathrm{~nm}$ showed a strong excitonic absorption peak in the UV region at $310 \mathrm{~nm}$ corresponding to electron transition (withdrawal) from the conduction band of $\mathrm{n}$-type (that is anion-deficient) $\mathrm{ZnO}_{1-x}$ to the valence band. See Figure 5 for the UV-Vis absorption spectra of $\mathrm{ZnO}$ and $\mathrm{ZnO}: \mathrm{H}$, respectively.

The $310 \mathrm{~nm}$ band of excitation corresponds to an optical band gap of $3.99 \mathrm{eV}$ above $3.7 \mathrm{eV}$ reported in literature [3]. Despite other weaker excitonic absorptions at $340 \mathrm{~nm}$ $(3.635 \mathrm{eV})$ and $450 \mathrm{~nm}(2.75 \mathrm{eV})$ probably due to inelastic scattering of charge by interacting phonons as the time progressed, the band at $310 \mathrm{~nm}$ was significant as it had a corresponding strong absorption by the $\mathrm{ZnO}$ (anionic rich) sample $[2,3,12]$. However, both samples had similar excitonic absorption at $450 \mathrm{~nm}$. The observed differences in optical 


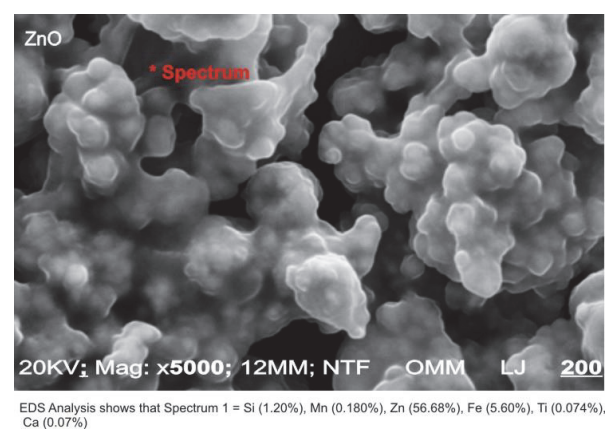

(a)

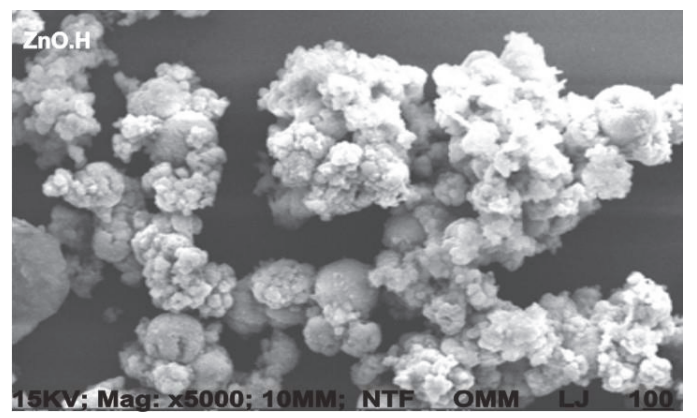

(c)

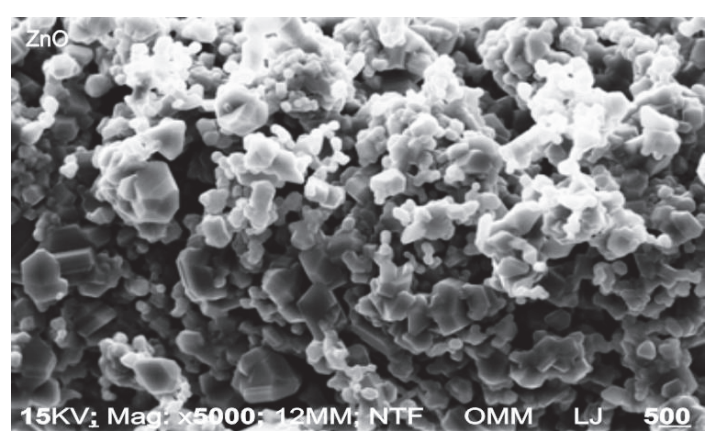

(b)

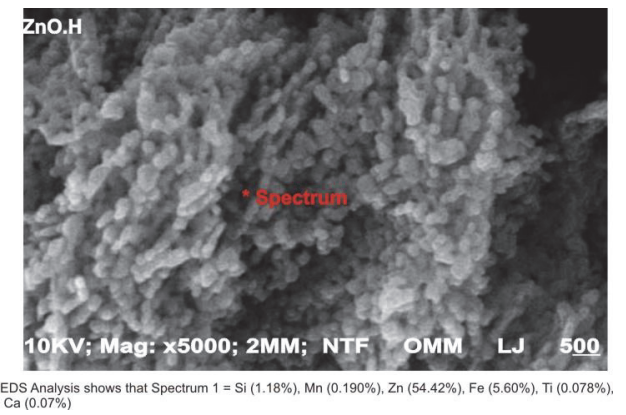

(d)

FIGURE 4: SEM micrographs of $0.02 \%$ starch (a-b) $\mathrm{ZnO}$ and (c-d) $\mathrm{ZnO}: \mathrm{H}_{(2)}$, respectively, with their EDS on (a) and (d), respectively.

behavior of the two samples in the UV region confirmed the structural changes due to $\mathrm{H}$ insertion. Hence, further studies were carried out on the $0,0.05$, and $0.15 \%$ starch-mediated $\mathrm{ZnO}$ and $\mathrm{ZnO}: \mathrm{H}_{(\mathrm{a})}$ samples, respectively, using the FT-IR spectroscopy in order to observe $\mathrm{H}$ insertion effect on the $\mathrm{Zn}$ O bonds.

The results (spectra) of the FT-IR analysis of the samples are shown in Figures 6(a)-6(f). Infrared finger print region of most metal oxides occurs below $1000 \mathrm{~cm}^{-1}$ and the characteristic $\mathrm{Zn}-\mathrm{O}$ vibration bands $\left(430-560 \mathrm{~cm}^{-1}\right)$ also lie in this region [10]. It was observed that the $\mathrm{ZnO}$ sample bands within these region became broadened with intense blue shift in their corresponding $\mathrm{ZnO}: \mathrm{H}$ sample bands. For example, $\mathrm{ZnO}$ band $(0 \%)$ at $552 \mathrm{~cm}^{-1}$ shifted to $515 \mathrm{~cm}^{-1}$ with a shoulder at $533 \mathrm{~cm}^{-1}$ for its corresponding $\mathrm{ZnO}: \mathrm{H}(0 \%)$ sample (Figures 6(a) and 6(b)).

Similar observations were made for $\mathrm{Zn}-\mathrm{O}$ stretching bands at 1500-1640 $\mathrm{cm}^{-1}$ [3] (Figures 6(a), 6(c), and 6(e)). However, with the $\mathrm{H}$ replacement of some $\mathrm{O}$ atoms, the $\mathrm{Zn}-\mathrm{O}$ stretching vibrations merged into single but intense $\mathrm{Zn}-\mathrm{O}-\mathrm{H}$ stretching at $1633-1638 \mathrm{~cm}^{-1}$ for all corresponding $\mathrm{ZnO}: \mathrm{H}$ samples (Figures 6(b), 6(d), and 6(f)). This led to the disappearance of all peaks around $1500 \mathrm{~cm}^{-1}$ in the $\mathrm{ZnO}: \mathrm{H}$ samples. Thus all the $\mathrm{ZnO}: \mathrm{H}(0,0.05$, and $0.15 \%$ starchmediated) samples showed fewer bands due to the merged peaks (Figures 6(b), 6(d), and 6(f)). The crystallinity of the samples decreased with the addition of starch such that seven bands were lost between $0 \%$ and $0.05 \%$ of added starch

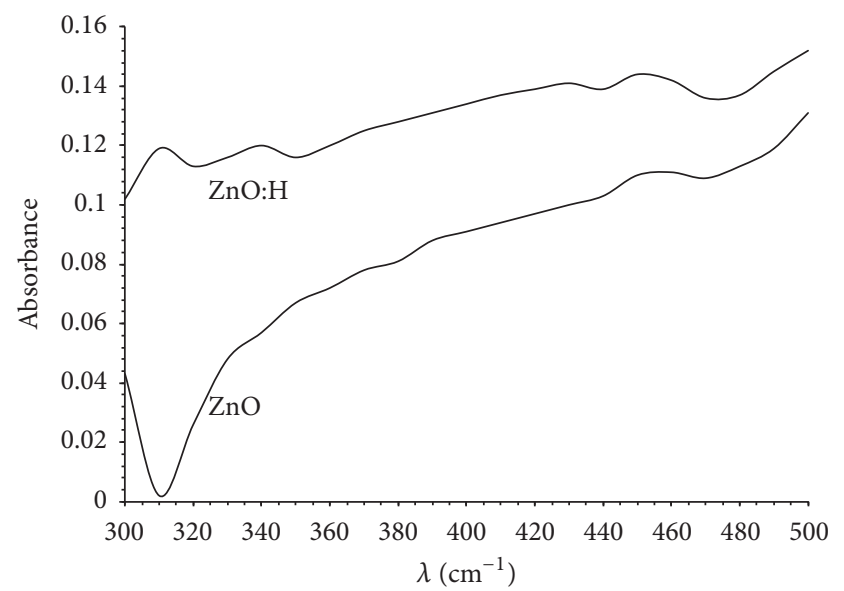

Figure 5: UV-Vis absorption spectra of $\mathrm{ZnO}$ and $\mathrm{ZnO}: \mathrm{H}$ as a function of wavelength.

concentration. Further decrease was observed with the addition of hydrogen. The FT-IR bands of $\mathrm{ZnO}$ and $\mathrm{ZnO}: \mathrm{H}$ are also contained in Table 2 of the supplementary information data sheet. Broad bands at 2000-3444 and $1114 \mathrm{~cm}^{-1}(0 \%$ $\mathrm{ZnO}: \mathrm{H})$ were assigned to $\mathrm{O}-\mathrm{H}$ stretching and deformation, respectively, from adsorbed moisture on sample surface due to preparation in air [3]. Similar adsorbed free $\mathrm{CO}_{2}$ from the air might be responsible for the band at $1384 \mathrm{~cm}^{-1}$ present in all the samples including the control (0\%). 


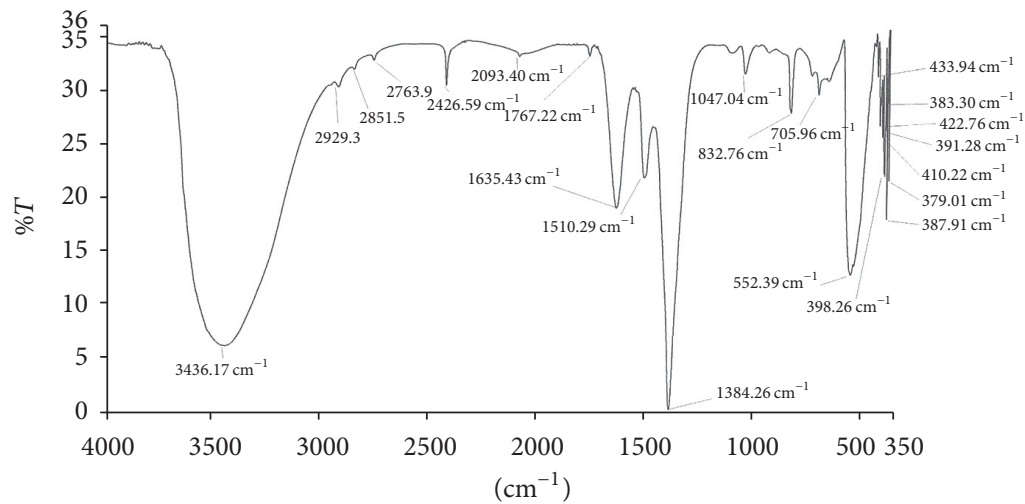

(a)

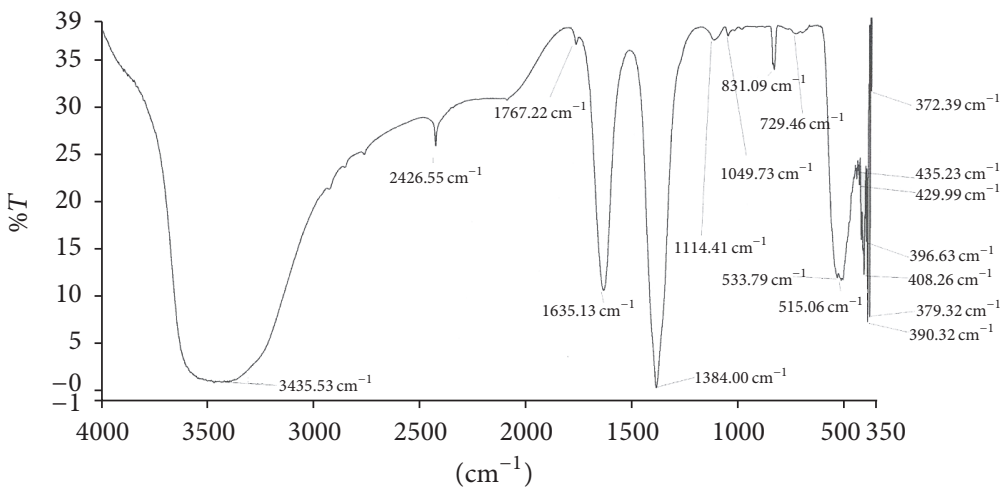

(b)

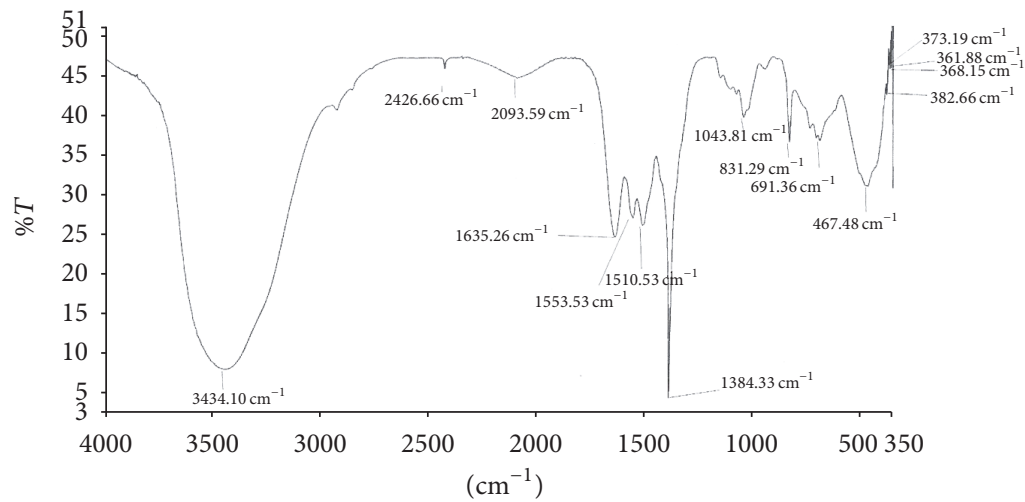

(c)

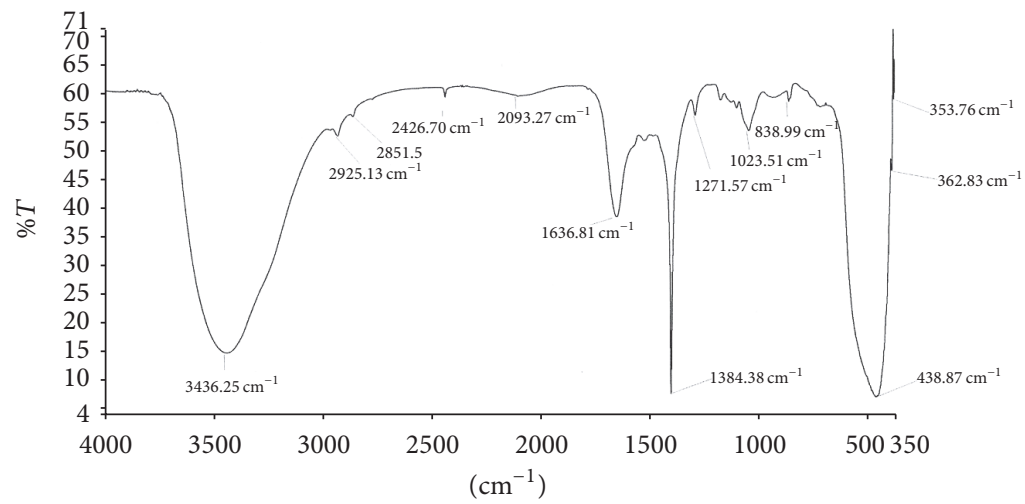

(d)

Figure 6: Continued. 


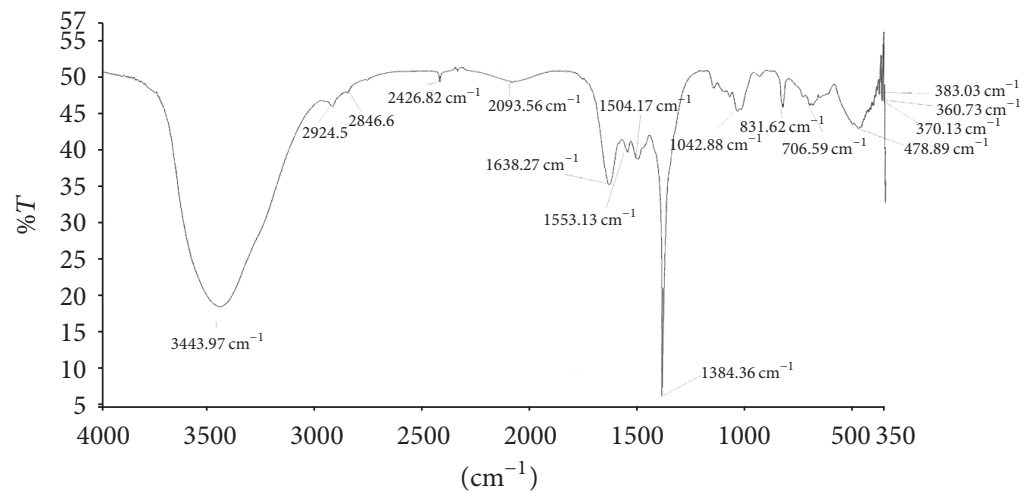

(e)

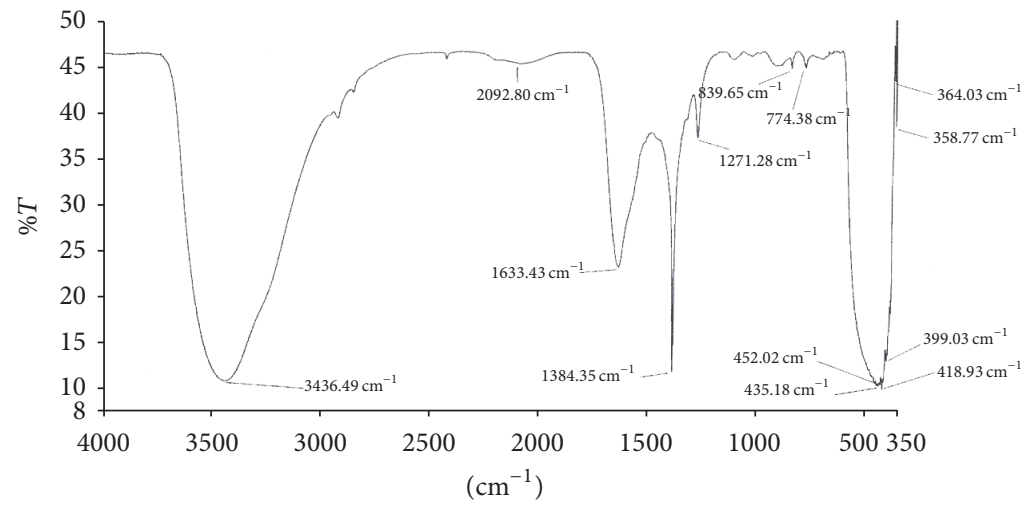

(f)

Figure 6: (a-f) FT-IR of $\mathrm{ZnO}$ and their corresponding $\mathrm{ZnO}: \mathrm{H}$ samples at 0, 0.05, and 0.15\% starch content of precursor solutions. (a) FT-IR of zinc oxide; $\mathrm{ZnO}$ synthesized using precursors in deionized water only, $0 \%$ starch (control). (b) FT-IR of hydrogenated zinc oxide; $\mathrm{ZnO}$ :H synthesized from precursors in deionized water only, $0 \%$ starch. (c) FT-IR of zinc oxide; ZnO synthesized using precursors in $0.05 \%$ starch solution. (d) FT-IR of hydrogenated zinc oxide; ZnO:H synthesized from precursors in $0.05 \%$ starch solution. (e) FT-IR of zinc oxide; ZnO synthesized using precursors in $0.15 \%$ starch solution. (f) FT-IR of hydrogenated zinc oxide; $\mathrm{ZnO}$ :H synthesized from precursors in $0.15 \%$ starch solution.

\section{Conclusion}

The sol-gel synthesis of $\mathrm{ZnO}$ and $\mathrm{ZnO}: \mathrm{H}$ phases via a simple adaptable technique has been reported. The XRD results of both samples showed reflections that were indexed to standard $\mathrm{ZnO}$ pattern. However, the emergence of a new peak due to $\mathrm{H}$ insertion into the $\mathrm{ZnO}$ lattice was observed at $2 \theta$, $29.60^{\circ}$ for $\mathrm{ZnO}: \mathrm{H}_{(\mathrm{a})}$, and confirmed with intense peak from a more hydrogenated $\mathrm{ZnO}: \mathrm{H}_{(\mathrm{b})}$. Lower conductivity value of $27.50 \mu \mathrm{S} / \mathrm{cm}$ as well as the estimated particle size of $30 \mathrm{~nm}$ was recorded for $\mathrm{ZnO}: \mathrm{H}_{(\mathrm{a})}$ compared to $30.90 \mu \mathrm{S} / \mathrm{cm}$ and $47 \mathrm{~nm}$ for the $\mathrm{ZnO}$ samples, respectively. Evidence of $\mathrm{H}$ insertion in $\mathrm{ZnO}: \mathrm{H}_{(\mathrm{a})}$ samples was supported by the distinct excitonic electronic transition occurring concomitantly with strong absorption by $\mathrm{ZnO}$ samples at $310 \mathrm{~nm}$ in the UV region. The SEM of the $0.02 \% \mathrm{ZnO}$ appeared more microporous and fiber-like than those of $0.01 \%$ starch-mediated samples, indicating that control over particle size was achieved via varying starch concentration, while the EDX confirmed $\mathrm{Zn}$ and $\mathrm{O}$ as the main components of the two samples. Higher magnification SEM of $0.02 \% \mathrm{ZnO}: \mathrm{H}_{(\mathrm{b})}$ showed the presence of smaller grained polycrystallites surrounding larger balllike polycrystallites indicating the biphasic microstructures due to $\mathrm{H}$ insertion. FT-IR results showed possible decrease in crystallinity (loss of bands) due to the presence of starch and further decrease upon $\mathrm{H}$ addition. Enhancement of IR bands at $430-552$ (Zn-O vibrations) and $1500-1640 \mathrm{~cm}^{-1}$ ( $\mathrm{Zn}-\mathrm{O}$ stretching) for the corresponding $\mathrm{ZnO}: \mathrm{H}$ samples was also observed.

\section{Competing Interests}

The authors declare that there are no competing interests regarding the publication of this article.

\section{Acknowledgments}

The authors wish to acknowledge the Centre of Nanotechnology and Advanced Materials, Engineering Development Institute (EMDI), Akure, Ondo State, for the X-ray diffraction facility used and also the Materials Laboratory of Kwara State University, Illorin, for their SEM and EDX facilities. They would also like to thank Mr. F. Chioma of the University of Ibadan for the FT-IR analysis and Tetfund, Nigeria, for conference sponsorship. 


\section{References}

[1] P. W. Atkins, T. Overtone, J. Rourke, M. Weller, and F. Armstrong, Inorganic Chemistry, Oxford University Press, Oxford, UK, 5th edition, 2010.

[2] A. S. Shaporev, V. K. Ivanov, A. E. Baranchikov, O. S. Polezhaeva, and Y. D. Tret'yakov, "ZnO formation under hydrothermal conditions from zinc hydroxide compounds with various chemical histories," Russian Journal of Inorganic Chemistry, vol. 52, no. 12, pp. 1811-1816, 2007.

[3] H. Kumar and R. Rani, "Structural and optical characterization of $\mathrm{ZnO}$ nanoparticles synthesized by microemulsion route," International Letters of Chemistry, Physics and Astronomy, vol. 19, pp. 26-36, 2013.

[4] R. A. McBride, J. M. Kelly, and D. E. McCormack, "Growth of well-defined $\mathrm{ZnO}$ microparticles by hydroxide ion hydrolysis of zinc salts," Journal of Materials Chemistry, vol. 13, no. 5, pp. 1196-1201, 2003.

[5] C. G. Van de Walle, "Hydrogen as a cause of doping in zinc oxide," Physical Review Letters, vol. 85, no. 5, pp. 1012-1015, 2000.

[6] A. Janotti and C. G. Van De Walle, "Hydrogen multicentre bonds," Nature Materials, vol. 6, no. 1, pp. 44-47, 2007.

[7] E. V. Lavrov, "Hydrogen in ZnO: an infra-red absorption study," Defect and Diffusion Forum, vol. 226-228, no. 1, pp. 181-189, 2004.

[8] C. G. Van de Walle, "Hydrogen interactions with semiconductors and oxides," in Proceedings of the 1st International Workshop on Hydrogen in Materials and Vacuum Systems, G. R. Myneni and Chattopadhyay, Eds., vol. 671 of AIP Conference Proceedings, pp. 33-39, 2003.

[9] A. Abliz, C.-W. Huang, J. Wang et al., "Rational design of $\mathrm{ZnO}: \mathrm{H} / \mathrm{ZnO}$ bilayer structure for high-performance thin-film transistors," ACS Applied Materials and Interfaces, vol. 8, no. 12, pp. 7862-7868, 2016.

[10] K. Ghule, A. V. Ghule, B.-J. Chen, and Y.-C. Ling, "Preparation and characterization of $\mathrm{ZnO}$ nanoparticles coated paper and its antibacterial activity study," Green Chemistry, vol. 8, no. 12, pp. 1034-1041, 2006.

[11] "Hydrothermal synthesis of hydrated zinc oxide nanoparticles and its characterization," Chemical Science Transactions, vol. 2, no. S1, pp. S33-S36, 2013.

[12] Y. Dimitriev, M. Gancheva, and R. Iordanova, "Synthesis of zno by mechanochemical decomposition of zinc carbonate hydroxide," Journal of the University of Chemical Technology and Metallurgy, vol. 46, no. 3, pp. 243-248, 2011.

[13] F. Ahmed, S. Kumar, N. Arshi, M. S. Anwar, and R. Prakash, "Growth and characterization of $\mathrm{ZnO}$ nanorods by microwaveassisted route: Green chemistry approach," Advanced Materials Letters, vol. 2, no. 3, pp. 183-187, 2011.

[14] K. Nejati, Z. Rezvani, and R. Pakizevand, "Synthesis of ZnO nanoparticles and investigation of the ionic template effect on their size and shape," International Nano Letters, vol. 1, pp. 7581, 2011.

[15] A. Khorsand Zak, R. Razali, W. H. Abd Majid, and M. Darroudi, "Synthesis and characterization of a narrow size distribution of zinc oxide nanoparticles," International Journal of Nanomedicine, vol. 6, no. 1, pp. 1399-1403, 2011.

[16] J. F. Muth, R. M. Kolbas, A. K. Sharma, S. Oktyabrsky, and J. Narayan, "Excitonic structure and absorption coefficient measurements of $\mathrm{ZnO}$ single crystal epitaxial films deposited by pulsed laser deposition," Journal of Applied Physics, vol. 85, no. 11, pp. 7884-7887, 1999.
[17] H. J. Chang, C. Z. Lu, Y. Wang et al., "Optical properties of ZnO nanocrystals synthesized by using sol-gel method," Journal of the Korean Physical Society, vol. 45, no. 4, pp. 959-962, 2004.

[18] S. Dutta and B. N. Ganguly, "Characterization of ZnO nanoparticles grown in presence of Folic acid template," Journal of Nanobiotechnology, vol. 10, article 29, 2012.

[19] S. Anita, T. Ramachandran, R. Rajendran, C. V. Koushik, and M. Mahalakshmi, "Preparation and characterization of zinc oxide nanoparticles and a study of the anti-microbial property of cotton fabric treated with the particles," Journal of Textile and Apparel, Technology and Management, vol. 6, no. 4, 2010.

[20] C. G. Van de Walle, "Hydrogen in materials and vacuum systems," in Proceedings of the 1st International Workshop on Hydrogen in Materials and Vacuum Systems, G. R. Myneni and S. Chattopadhyay, Eds., vol. 671 of AIP Conference Proceedings, pp. 33-39, Newport News, Va, USA, November 2002.

[21] W. M. Hlaing Oo and M. D. McCluskey, "Infrared spectroscopy of impurities in $\mathrm{ZnO}$ nanoparticles," MRS Proceedings, vol. 864, E4.40, 2005.

[22] S. J. Jokela, M. D. McCluskey, and K. G. Lynn, "Infrared spectroscopy of hydrogen in annealed zinc oxide," Physica B: Condensed Matter, vol. 340-342, pp. 221-224, 2003.

[23] Z. Zhang, D. C. Look, R. Schifano, K. M. Johansen, B. G. Svensson, and L. J. Brillson, "Process dependence of $\mathrm{H}$ passivation and doping in $\mathrm{H}$-implanted $\mathrm{ZnO}$," Journal of Physics D: Applied Physics, vol. 46, no. 5, Article ID 055107, 2013.

[24] H. E. Swanson and R. K. Fuyat, "Standard X-ray diffraction powder patterns," National Bureau of Standards (U.S.), Monograph 25, Circular 539, vol. 1, 1953.

[25] B. Fultz and J. M. Howe, Transmission Electron Microscopy and Diffraction of Materials (Graduate Texts in Physics), Springer, Berlin, Germany, 4th edition, 2013.

[26] J. L. Konne and K. Okpara, "Remediation of nickel from crude oil obtained from bomu oil field using cassava waste water starch stabilized magnetic nanoparticles," Energy and Environment Research, vol. 4, no. 1, pp. 25-31, 2014. 

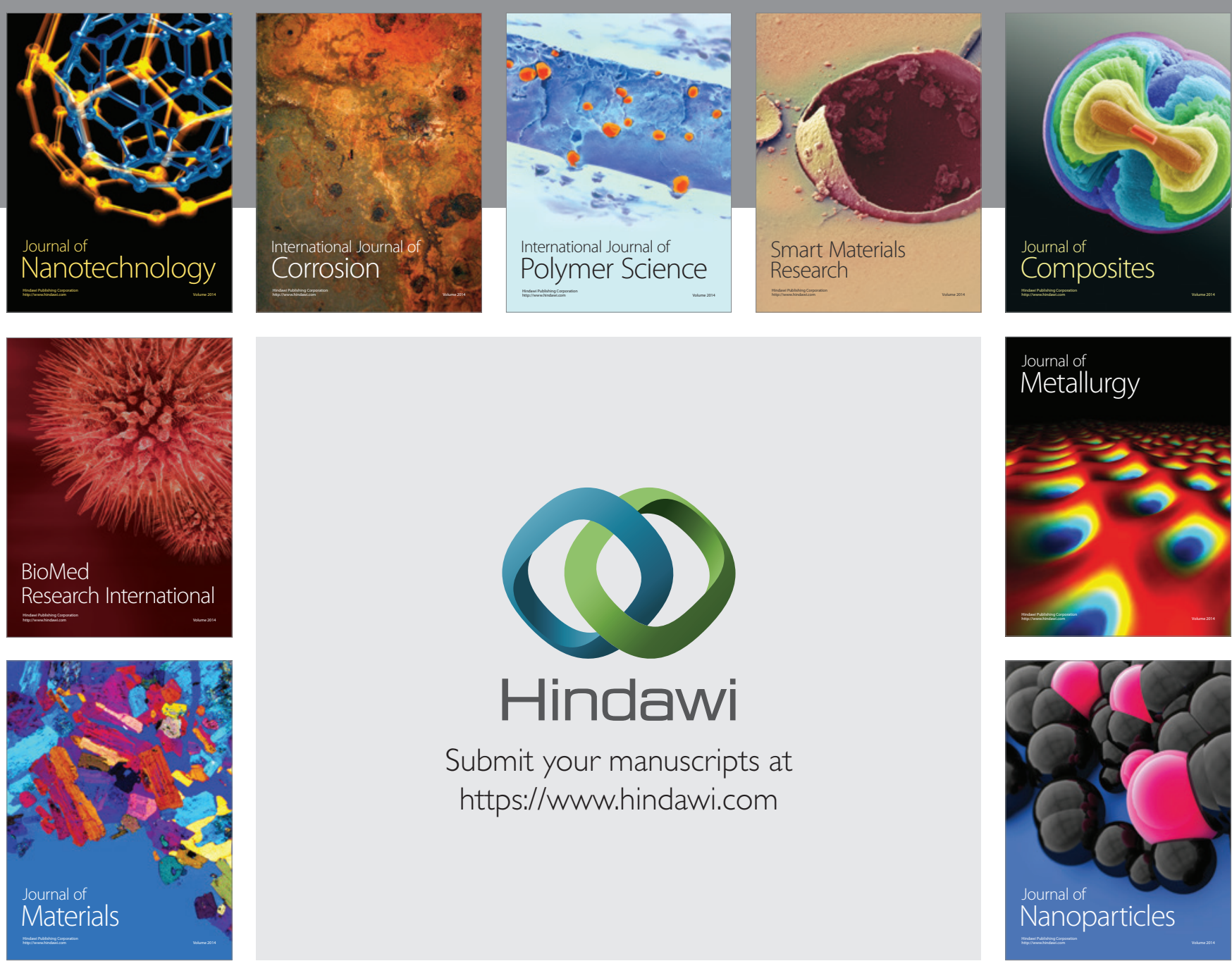

\section{Hindawi}

Submit your manuscripts at

https://www.hindawi.com

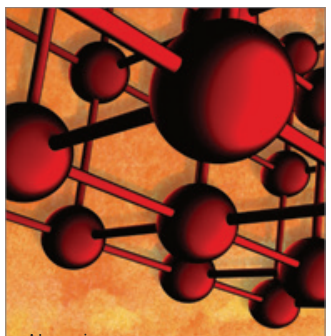

Materials Science and Engineering
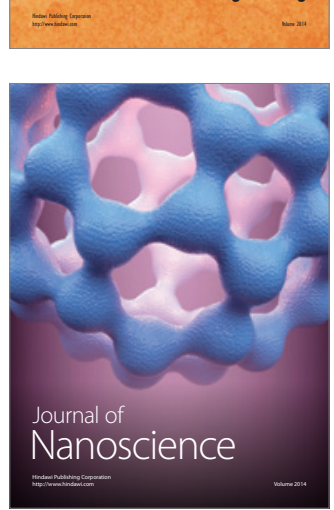
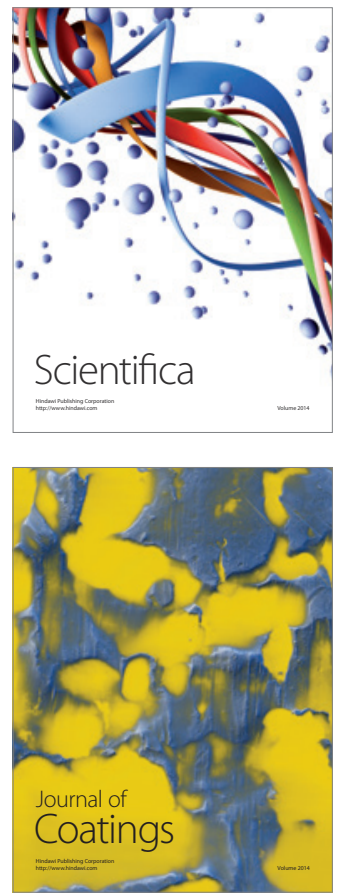
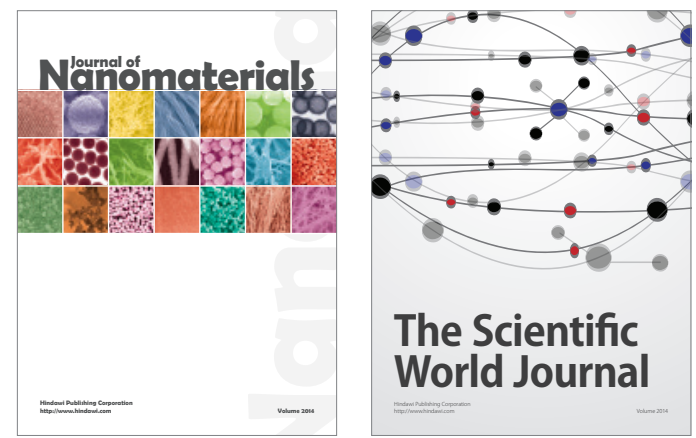

The Scientific World Journal
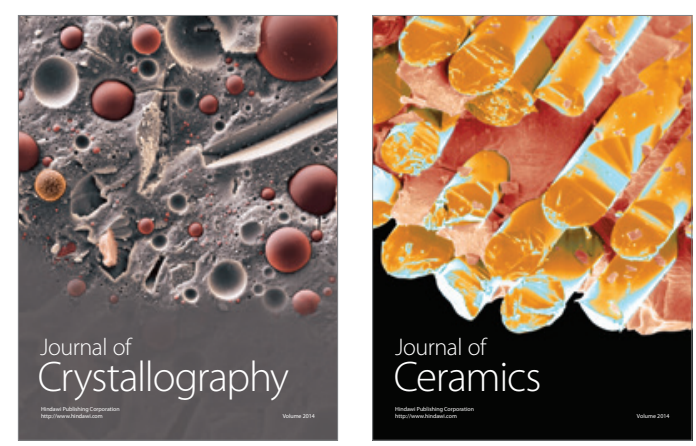
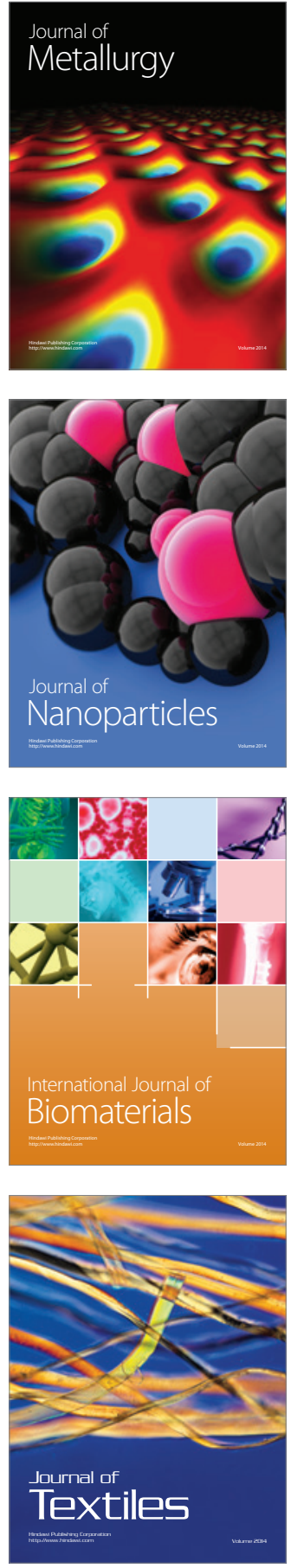